\title{
Platelet to white blood cell ratio predicts 30-day postoperative infectious complications in patients undergoing radical nephrectomy for renal malignancy
}

\author{
Alaina Garbens, MD¹; Christopher J.D. Wallis, MD²; Georg Bjarnason, MD²; Girish S. \\ Kulkarni, MD, $\mathrm{PhD}^{4}$; Avery B. Nathens, MD, $\mathrm{PhD}^{3}$; Robert K. Nam, MD, $\mathrm{MSc}^{1}$; Raj \\ Satkunasivam, MD, $\mathrm{MS}^{1}$ \\ ${ }^{1}$ Division of Urology, Department of Surgery, Sunnybrook Health Sciences Centre, University of Toronto, ON, \\ Canada; ${ }^{2}$ Division of Medical Oncology, Department of Medicine, Sunnybrook Health Sciences Centre, University \\ of Toronto, ON, Canada; ${ }^{3}$ Division of General Surgery, Department of Surgery, Sunnybrook Health Sciences \\ Centre, University of Toronto, ON, Canada; ${ }^{4}$ Division of Urology, Department of Surgery, Princess Margaret \\ Hospital and University Health Network, University of Toronto, ON, Canada
}

Cite as: Can Urol Assoc J 2017; Epub ahead of print. http://dx.doi.org/10.5489/cuaj.4478

\section{Published online November 1, 2017}

$* * *$

\section{Abstract}

Introduction: We sought to examine the relationship between preoperative platelet to white blood cell ratio (PLT/WBC), a hematologic marker of the systemic inflammatory response, and postoperative infectious complications following radical nephrectomy for localized renal cell carcinoma.

Methods: We performed a retrospective cohort study of patients treated with radical nephrectomy for localized kidney cancer between January 1, 2005 and December 31, 2014 ( $n=6235$ ) using the American College of Surgeons (ACS) National Surgical Quality Improvement Program (NSQIP) database. Univariate and multivariate analyses were used to assess the association between PLT/WBC ratio and 30-day infectious complications, including surgical site infection, urinary tract infection, pneumonia, and sepsis. Secondarily, we examined major complications and bleeding requiring transfusion.

Results: A lower PLT/WBC ratio was associated with an increased risk of sepsis, pneumonia, and UTI rates ( $<<0.05$ for all). Furthermore, there was a significant trend of decreasing rates of sepsis and pneumonia with increasing PLT/WBC ratio, across quintiles ( $\mathrm{p}<0.05$ for all). On multivariate analysis, patients with the lowest PLT/WBC ratios (quintile 1) had a two-fold risk of having a postoperative infectious complication compared to patients in the highest quintile (odds ratio [OR] 2.01; 95\% confidence interval [CI] 1.42-2.86; $\mathrm{p}<0.0001$ ). Patients in quintile 5 had a higher risk of requiring blood transfusion than those in quintiles $2-4$ ( $\mathrm{p}<0.05$ for all).

Conclusions: The PLT/WBC ratio represents a widely available and novel index to predict risk of infectious and bleeding complications in patients undergoing radical nephrectomy. External validation is required and the biological underpinning of this phenomenon requires further study. 


\section{Introduction}

Renal cell carcinoma is the ninth most common cancer in the United States and its incidence has been increasing in developed countries. ${ }^{12}$ The vast majority of patients present with localized disease. ${ }^{12}$ Surgical extirpation, by radical or partial nephrectomy, remains the standard of care for these patients. ${ }^{3}$ Post-operative complications and re-admission rates following radical nephrectomy have been reported to be as high as 30\%. ${ }^{5}$ We previously identified bleeding (requiring transfusion) and infectious complications to be the most common post-operative complications. ${ }^{6}$ While patient comorbidities are known to predict post-operative complications, ${ }^{7}$ 8 the risk is difficult to quantify depending on number and type. A simple test that could quickly assess perioperative risk in the clinic would be useful in counseling patients.

The systemic inflammatory response may be involved in kidney cancer progression and kidney tumor cell biology, and may have utility as a prognostic biomarker. ${ }^{9}{ }^{10}$ These scoring systems are calculated using hematologic tests which are routinely collected pre-operatively. ${ }^{1}$ While their usefulness in predicting prognosis in localized renal cell carcinoma has recently been demonstrated, ${ }^{11}$ the small number and heterogeneity of studies as well as the lack of large multiinstitutional data, limits wider adoption. ${ }^{1}$ The platelet to white blood cell count (PLT/WBC) has demonstrated prognostic ability for mortality and long-term outcomes following myocardial infarction, ${ }^{12} 13$ but its association with perioperative outcomes has not been fully assessed. ${ }^{14}$ The PLT/WBC ratio would be an ideal marker for perioperative outcomes as it is easily calculated and routinely collected prior to major surgery.

We hypothesized that there may be a relationship between the systemic inflammatory response and post-operative infections. We sought to evaluate the association between preoperative PLT/WBC ratio and post-operative infectious complications among patients undergoing radical nephrectomy for localized kidney cancer. Secondarily, we examined the relationship between the preoperative PLT/WBC ratio and post-operative bleeding complications. In order to do so, we utilized the National Surgical Quality Improvement Program (NSQIP), a multi-institutional registry developed by the American College of Surgeons (ACS). ${ }^{15}$ Studies have found NSQIP to more accurately identify 30-day post-operative patient outcomes compared to single center or administrative data sources. ${ }^{16-18}$

\section{Methods}

\section{Study design and population}

We performed a retrospective cohort study of patients aged 18 years and older who underwent a radical nephrectomy for kidney cancer between January 1, 2005 and December 31, 2014 using the American College of Surgeons (ACS) National Surgical Quality Improvement Program (NSQIP) database. NSQIP employs surgical clinical reviewers who collect validated preoperative and perioperative data until 30 days after surgery on patients at participating hospitals. ${ }^{15}$ Its registry includes over 700 hospitals and is focused on reporting and improving perioperative outcomes. $^{19}$

We identified patients undergoing radical nephrectomy using Common Procedural Terminology (CPT) codes (CPT 50220, 50225, 50230, 50545 and 50546) who had complete data for pre-operative platelet and white blood cell count. We subsequently restricted our cohort to 
patients with a post-operative diagnosis of kidney cancer (ICD-9 codes 189 or 189.0). Patients with a cancer diagnosis were chosen as previous studies have linked the systemic inflammatory response to cancer prognosis. ${ }^{9} 20$ Patients younger than 18 years $(n=2)$ and those missing data on weight ( $n=47)$, height $(n=99)$, length of stay $(n=3)$ or American Society of Anesthesiology (ASA) class $(n=16)$ were excluded. ${ }^{6}$ Finally, patients with disseminated cancer $(n=588)$, missing hematocrit $(n=4)$ or gender $(n=3)$ were excluded from our final analysis.

\section{Exposure and covariates}

Our exposure of interest was pre-operative platelet (PLT, $10^{3} /$ microliter) to white blood cell (WBC, number of WBC/microliter) ratio (PLT/WBC), categorized as quintiles. We abstracted data on a priori selected covariates based on a literature review to identify pre-operative patient factors that may affect post-operative outcomes and may thus confound the relationship between PLT/WBC ratio and perioperative complications. These covariates included age, gender, race, American Society of Anesthesiologists (ASA) score, body mass index (BMI kg/m²), smoking status (active smoker within one year of surgery), history of cardiac disease, history of diabetes (requiring oral medication or insulin therapy), history of neurologic disease, history of chronic obstructive pulmonary disease (COPD), requirement for hemodialysis, functional status (dependent, partially dependent, independent and unknown), chronic steroid use, surgical technique (laparoscopic vs. open) and preoperative anemia (hematocrit <39\%).

\section{Outcome}

Our primary outcome was infectious complications (surgical site infections, pneumonia, urinary tract infection or sepsis) within 30 days after surgery. Secondary outcomes included bleeding requiring transfusion and major complications within 30 days. Major complications included mortality, reoperation, neurological event (stroke or coma) and/or cardiac event (myocardial infarction or cardiac arrest). These outcome were chosen as they are major contributors to patient mortality, morbidity and increased healthcare costs. ${ }^{21}$

\section{Statistical analysis}

Baseline demographic variables were assessed using frequencies and proportions for categorical variables, means and standard deviations for normally-distributed continuous variables, and medians and interquartile ranges for non-normal continuous variables. We compared differences between PLT/WBC ratio quintiles using the Pearson chi-squared test for categorical variables and one-way analysis of variances (ANOVA) for continuous variables. For variables with ordinal structure, we assessed trends across the quintiles using the Cochran-Armitage test for trend.

We compared the proportion of cases resulting in a complication between each of our quintiles. We assessed for differences between the quintiles using the Pearson chi-squared test and examined trends across quintiles using the Cochran-Armitage test. Multivariable logistic regression modeling was used to assess the association between PLT/WBC ratio and each outcome while adjusting for age, gender, race, BMI category, ASA class, history of cardiac disease, diabetes, COPD, neurologic disease, on dialysis, chronic use of steroids, functional status, anemia and smoking status. 
Statistical significance was set at p-value equal to 0.05. All tests were two tailed and all statistical analyses were performed using SPSS v24 (IBM Corp., Armonk, NY, USA).

\section{Results}

We identified 6,235 eligible patients who underwent radical nephrectomy for localized kidney cancer during the study period. We found that both lower pre-operative WBC as well as higher pre-operative PLT counts were responsible for the observed variation in PLT/WBC ratio (Table 1). Patients in the lowest quintile were older, more likely to be male, have medical comorbidities, to have undergone laparoscopic surgery and be of non-African descent than patients in higher quintiles (Table 1).

An increasing PLT/WBC ratio was associated with a decreasing risk of 30-day postoperative infectious complications ( $<<0.0001$, Table 2$)$. Univariate analysis examining each site of infection demonstrated a significant difference between quintiles for sepsis, pneumonia and urinary tract infections with significant trend for decreasing complication rate with increasing PLT/WBC quintile for both sepsis and pneumonia (Table 2). While there appeared to be a decreasing trend for UTIs with increasing PLT/WBC quintiles, this was not significant $(\mathrm{p}=0.14)$. There was no significant difference in surgical site infection rates between quintiles $(\mathrm{p}=0.38)$. After multivariable regression, patients with low PLT/WBC ratio (Quintiles 1 and 2) had a significantly higher risk of infectious complication compared to patients in Quintile 5 (Table 3).

Among our secondary outcomes, there was a significant difference in transfusion rates, but not major complication rates between PLT/WBC quintiles (Table 2). Further, there was a significant trend for higher transfusion rates among patients in higher quintiles (Cochran Armitage test for trend, $\mathrm{p}=0.0009$ ). On multivariable analysis, patients in Quintiles 2, 3 and 4 had significantly lower odds of requiring transfusion compared to Quintile 5 (Table 3). There was no significant difference in major complication rates between quintiles on either univariate or multivariable analyses (Tables 2 and 3).

\section{Discussion}

Using a large, prospectively-collected and validated multi-institutional registry, we identified platelet to white blood cell (PLT/WBC) ratio as a novel, independent predictor of infectious and bleeding complications following radical nephrectomy for kidney cancer. While PLT/WBC ratio was strongly related to baseline patient characteristics including age and comorbidity, a lower PLT/WBC ratio (Quintile 1) was independently associated with a 2-fold higher risk of infectious complications compared to patients in the highest PLT/WBC quintile (Quintile 5) after adjusting for these characteristics. Further, a higher PLT/WBC ratio was independently associated with higher risk of requiring blood transfusion compared to lower PLT/WBC ratios (Quintiles 2, 3 and 4). The major complication rate for the whole cohort was low, consistent with rates reported in the literature, ${ }^{22}$ and not associated with the PLT/WBC ratio.

To the best of our knowledge, this is the first study to identify PLT/WBC ratio as a predictor of post-operative complications in surgical patients with localized cancer. Previous studies have used other hematologic markers as surrogates to the inflammatory response to predict prognosis in patients with metastatic and localized disease. ${ }^{11123}$ However, the use of such markers to predict short-term outcomes has not been previously studied. Furthermore, these 
calculations usually require neutrophil and lymphocytes counts, data that is not uniformly collected in registry databases.

It is notable that PLT/WBC ratio was significantly associated with sepsis, pneumonia and urinary tract infection but not wound infections. Wound infections are much more likely to be influenced by technical considerations including skin preparation, shaving and wound closure, ${ }^{24}$ in addition to patient factors, as compared to other sites of infection. Further, because radical nephrectomy incisions are considered clean, SSI are rare. ${ }^{25}$

The mechanistic relationship between PLT/WBC ratio and infection remains to be elucidated. One possibility is that the PLT/WBC ratio is a surrogate for a patient's baseline health status. Patients with low ratios were more likely to have more comorbidities (diabetes, COPD, dialysis dependence, use of chronic steroids) and to be current smokers, which are all known to alter the inflammatory response and are risk factors for post-operative infections. ${ }^{26}{ }^{27}$ Furthermore, other studies have found poor health status (high BMI, >5\% weight loss, low albumin, lymphocyte count) of patients to result in worse post-operative outcomes in patients undergoing nephrectomy for renal cell carcinoma. ${ }^{28}$ Notably, PLT/WBC ratio remained an important predictor of infectious complications after adjusting for these factors. Further, this ratio is likely also an indicator of metabolic syndrome, a constellation of physiologic and biochemical abnormalities, resulting in inappropriate activation of inflammatory pathways. ${ }^{30}$ Metabolic syndrome is a wellknown risk factor for post-operative complications, including infection. ${ }^{273132}$

In addition to the association with infectious complications, PLT/WBC ratio was significantly associated with rates of bleeding requiring transfusion. Patients in the lowest quintile were overall in poorer general health compared to patients in higher quintiles and were more likely to have undergone laparoscopic surgery compared to patients in Quintile 5. These higher transfusion rates may be explained by the fact that a greater proportion of patients underwent open surgery in Quintile 5. Many studies have found higher transfusion rates with open compared to laparoscopic nephrectomy ${ }^{33} 34$. Indeed, in our model, open surgical technique was a strong predictor of increased transfusion risk (data not shown). Furthermore, it is unknown if patients undergoing open surgery had increased tumour complexity (data is not captured), which could increase risk of transfusion. Another explanation is that there are a higher proportion of female patients in Quintile 5 (49.7\%) compared to Quintile 1 (27.3\%). Biologically, females have lower hemoglobin levels compared to males. ${ }^{35}$ As these patients were treated at many different hospitals, it is unknown what parameters were used for initiating transfusion and how these may have differed between institutions.

We excluded patients with disseminated cancer at time of surgery, as studies have found these patients to be at increased risk of complications compared to patients with localized disease. ${ }^{636}$ Further, we excluded patients for whom the post-operative diagnosis was not explicitly recorded as kidney cancer. Thus, these results may not directly be extrapolated to patients with metastatic disease nor those undergoing nephrectomy for benign indications.

Despite the strengths of the NSQIP database, there are limitations to this analysis. As we used retrospective data, there are likely other confounders that were not included in our model that could be affecting complication rates. In addition, as NSQIP only captures complications within the first 30-days post-operation, the results may not apply to complications that occur 
beyond this period. NSQUIP does not collect information on tumour staging and renal nephrometry scores. As a result, we cannot comment on stage migration over time. However, epidemiological data suggest that due to imaging studies being performed for other indications, RCC is commonly found incidentally. ${ }^{37}$ This has led to a stage migration overall towards lower stage of disease at time of diagnosis. ${ }^{38}$

In order to provide clinically-meaningful interpretations of PLT/WBC ratio, we used quintiles. However, future research may identify more informative ways to operationalize this variable such as a dichotomous threshold. Currently, no such cutoff has been identified. As this study only examined PLT/WBC ratio in patients with RCC, its results may not be applicable to patients undergoing other procedures. Finally, we cannot assess whether neutrophil to lymphocyte ratio would perform similarly to PLT/WBC ratio.

It was our hypothesis that the PLT/WBC, a measure of the systemic inflammatory response, would reflect the overall health status of the patient, taking into account their medical comorbidities, cancer status and lifestyle. We found that the PLT/WBC ratio was associated with post-operative infections both in univariate analysis and independently in multivariable analyses accounting for these factors. Thus, this simple ratio may prove useful for busy clinicians, as it is easier to interpret this result than to integrate the risks of each predictive factor.

\section{Conclusion}

Our study is the first to examine usefulness of the PLT/WBC ratio in predicting short-term 30day post-operative outcomes in patients undergoing surgery for renal malignancy. Patients who had low PLT/WBC ratios had significantly higher odds of infectious complications compared to patients with high PLT/WBC ratios. Further studies need to be performed to verify these findings in other populations. 


\section{References}

1. Grimes N, Tyson M, Hannan C, et al. A Systematic Review of the Prognostic Role of Hematologic Scoring Systems in Patients With Renal Cell Carcinoma Undergoing Nephrectomy With Curative Intent. Clinical Genitourinary Cancer doi: http://dx.doi.org/10.1016/j.clgc.2016.01.006

2. Rendon RA, Kapoor A, Breau R, et al. Surgical management of renal cell carcinoma: Canadian Kidney Cancer Forum Consensus. (1911-6470 (Print)) doi: D - NLM: PMC4081255 EDAT- 2014/07/16 06:00 MHDA- 2014/07/16 06:01 CRDT- 2014/07/16 06:00 AID - 10.5489/cuaj.1894 [doi] AID - cuaj-5-6-e398 [pii] PST - ppublish

3. Ljungberg B, Bensalah K, Canfield S, et al. EAU Guidelines on Renal Cell Carcinoma: 2014 Update. European Urology 2015;67(5):913-24. doi: http://dx.doi.org/10.1016/j.eururo.2015.01.005

4. Ebbing J, Wiebach T, Kempkensteffen C, et al. Evaluation of perioperative complications in open and laparoscopic surgery for renal cell cancer with tumor thrombus involvement using the Clavien-Dindo classification. European Journal of Surgical Oncology (EJSO) 2015;41(7):941-52. doi: http://dx.doi.org/10.1016/j.ejso.2015.02.009

5. Hadjipavlou M, Khan F, Fowler S, et al. Partial vs radical nephrectomy for T1 renal tumours: an analysis from the British Association of Urological Surgeons Nephrectomy Audit. BJU International 2016;117(1):62-71. doi: 10.1111/bju.13114

6. Wallis CJ, Bjarnason G, Byrne J, et al. Morbidity and Mortality of Radical Nephrectomy for Patients with Disseminated Cancer - an Analysis of the National Surgical Quality Improvement Program Database. LID - S0090-4295(16)30274-6 [pii] LID 10.1016/j.urology.2016.04.055 [doi]. (1527-9995 (Electronic))

7. Novitsky YW, Orenstein SB. Effect of patient and hospital characteristics on outcomes of elective ventral hernia repair in the United States. Hernia 2013;17(5):639-45. doi: 10.1007/s10029-013-1088-5

8. Scrutinio D, Giannuzzi P. Comorbidity in patients undergoing coronary artery bypass graft surgery: impact on outcome and implications for cardiac rehabilitation. 2008(17418267 (Print))

9. Roxburgh CS, McMillan DC. Role of systemic inflammatory response in predicting survival in patients with primary operable cancer. (1744-8301 (Electronic))

10. Ramsey S, Lamb Gw Fau - Aitchison M, Aitchison M Fau - Graham J, et al. Evaluation of an inflammation-based prognostic score in patients with metastatic renal cancer. (0008-543X (Print))

11. Lucca I, de Martino M, Hofbauer SL, et al. Comparison of the prognostic value of pretreatment measurements of systemic inflammatory response in patients undergoing curative resection of clear cell renal cell carcinoma. World Journal of Urology 2015;33(12):2045-52. doi: 10.1007/s00345-015-1559-7

12. Dehghani Mr Fau - Rezaei Y, Rezaei Y, Taghipour-Sani L. White blood cell count to mean platelet volume ratio as a novel non-invasive marker predicting long-term 
outcomes in patients with non-ST elevation acute coronary syndrome. (1897-5593 (Electronic))

13. Cicek G, Acikgoz Sk Fau - Yayla C, Yayla C Fau - Kundi H, et al. White blood cell count to mean platelet volume ratio: A novel and promising prognostic marker for stsegment elevation myocardial infarction. LID - 10.5603/CJ.a2016.0001 [doi]. (18975593 (Electronic))

14. Ashrafganjoei T, Mohamadianamiri M Fau - Farzaneh F, Farzaneh F Fau - Hosseini MS, et al. Investigating Preoperative Hematologic Markers for Prediction of Ovarian Cancer Surgical Outcome. (1513-7368 (Print))

15. Cohen ME, Liu Y Fau - Ko CY, Ko Cy Fau - Hall BL, et al. Improved Surgical Outcomes for ACS NSQIP Hospitals Over Time: Evaluation of Hospital Cohorts With up to 8 Years of Participation. (1528-1140 (Electronic))

16. Davenport DL, Holsapple Cw Fau - Conigliaro J, Conigliaro J. Assessing surgical quality using administrative and clinical data sets: a direct comparison of the University HealthSystem Consortium Clinical Database and the National Surgical Quality Improvement Program data set. (1555-824X (Electronic))

17. Cima RR, Lackore KA, Nehring SA, et al. How best to measure surgical quality? comparison of the Agency for Healthcare Research and Quality Patient Safety Indicators (AHRQ-PSI) and the American College of Surgeons National Surgical Quality Improvement Program (ACS-NSQIP) postoperative adverse events at a single institution. Surgery 2011;150(5):943-49. doi: http://dx.doi.org/10.1016/j.surg.2011.06.020

18. Koch CG, Li L, Hixson E, et al. What Are the Real Rates of Postoperative Complications: Elucidating Inconsistencies Between Administrative and Clinical Data Sources. Journal of the American College of Surgeons 2012;214(5):798-805. doi: http://dx.doi.org/10.1016/j.jamcollsurg.2011.12.037

19. Ingraham AM, Richards KE, Hall BL, et al. Quality improvement in surgery: the American College of Surgeons National Surgical Quality Improvement Program approach. Adv Surg 2010;44:251-67.

20. Ramsey MT, Fabian TC, Shahan CP, et al. A prospective study of platelet function in trauma patients. J Trauma Acute Care Surg 2016;80(5):726-32; discussion 32-3. doi: 10.1097/TA.0000000000001017

21. Eappen S, Lane BH, Rosenberg B, et al. RElationship between occurrence of surgical complications and hospital finances. JAMA 2013;309(15):1599-606. doi:

10.1001/jama.2013.2773

22. De P, Otterstatter MC, Semenciw R, et al. Trends in incidence, mortality, and survival for kidney cancer in Canada, 1986-2007. Cancer Causes \& Control 2014;25(10):1271-81. doi: 10.1007/s10552-014-0427-x

23. Grimes N, Tyson M, Hannan C, et al. A Systematic Review of the Prognostic Role of Hematologic Scoring Systems in Patients With Renal Cell Carcinoma Undergoing Nephrectomy With Curative Intent. Clinical Genitourinary Cancer 2016;14(4):271-76. doi: http://dx.doi.org/10.1016/j.clgc.2016.01.006 
24. Gottrup F MA, Hollander DA. An overview of surgical site infection: aetiology, incidence and risk factors. European Wound Management Association Journal 2005;5(2):11-15.

25. Kortram K, Ijzermans JNM, Dor FJMF. Perioperative Events and Complications in Minimally Invasive Live Donor Nephrectomy: A Systematic Review and Meta-Analysis. Transplantation 9000;Online First doi: 10.1097/tp.0000000000001327

26. Klinger MH, Jelkmann W. Role of blood platelets in infection and inflammation. (10799907 (Print))

27. Dandona P, Aljada A, Chaudhuri A, et al. Metabolic Syndrome: A Comprehensive Perspective Based on Interactions Between Obesity, Diabetes, and Inflammation. Circulation 2005;111(11):1448-54.

28. Morgan TM, Tang D, Stratton KL, et al. Preoperative Nutritional Status Is an Important Predictor of Survival in Patients Undergoing Surgery for Renal Cell Carcinoma. European Urology 2011;59(6):923-28.

doi: http://dx.doi.org/10.1016/j.eururo.2011.01.034

29. Jeon HG, Choi DK, Sung HH, et al. Preoperative Prognostic Nutritional Index is a Significant Predictor of Survival in Renal Cell Carcinoma Patients Undergoing Nephrectomy. Annals of Surgical Oncology 2016;23(1):321-27. doi: 10.1245/s10434015-4614-0

30. Odrowaz-Sypniewska G. Markers of pro-inflammatory and pro-thrombotic state in the diagnosis of metabolic syndrome. (1896-1126 (Print))

31. Doyle SL, Lysaght J Fau - Reynolds JV, Reynolds JV. Obesity and post-operative complications in patients undergoing non-bariatric surgery. (1467-789X (Electronic))

32. Safranow K, Dziedziejko V, Rzeuski R, et al. Inflammation markers are associated with metabolic syndrome and ventricular arrhythmia in patients with coronary artery disease. (1732-2693 (Electronic))

33. Pak JS, Lee JJ, Bilal K, et al. Utilization trends and outcomes up to 3 months of open, laparoscopic, and robotic partial nephrectomy. J Robot Surg 2016 doi: 10.1007/s11701016-0650-4 [published Online First: 2016/11/03]

34. Ghani KR, Sukumar S, Sammon JD, et al. Practice Patterns and Outcomes of Open and Minimally Invasive Partial Nephrectomy Since the Introduction of Robotic Partial Nephrectomy: Results from the Nationwide Inpatient Sample. The Journal of Urology 2014;191(4):907-13. doi: http://dx.doi.org/10.1016/j.juro.2013.10.099

35. Bydon M, Abt NB, Macki M, et al. Preoperative anemia increases postoperative morbidity in elective cranial neurosurgery. Surgical Neurology International 2014;5:156. doi: 10.4103/2152-7806.143754

36. Moghadamyeghaneh Z, Hanna MH, Hwang G, et al. Outcomes of colon resection in patients with metastatic colon cancer. The American Journal of Surgery doi: http://dx.doi.org/10.1016/j.amjsurg.2016.01.025

37. Sweeney JP, Thornhill JA, Graiger R, et al. Incidentally detected renal cell carcinoma: pathological features, survival trends and implications for treatment. Br J Urol 1996;78(3):351-3. [published Online First: 1996/09/01] 
38. Nason GJ, McGuire BB, Kelly ME, et al. Clinico-pathological analysis of renal cell carcinoma demonstrates decreasing tumour grade over a 17-year period. Canadian Urological Association Journal 2014;8(3-4):125-32. doi: 10.5489/cuaj.1721 
Tables

Table 1. Demographic characteristics of patients treated with radical nephrectomy for localized kidney cancer, according to quintiles of platelet to white blood cell count (PLT/WBC) ratio

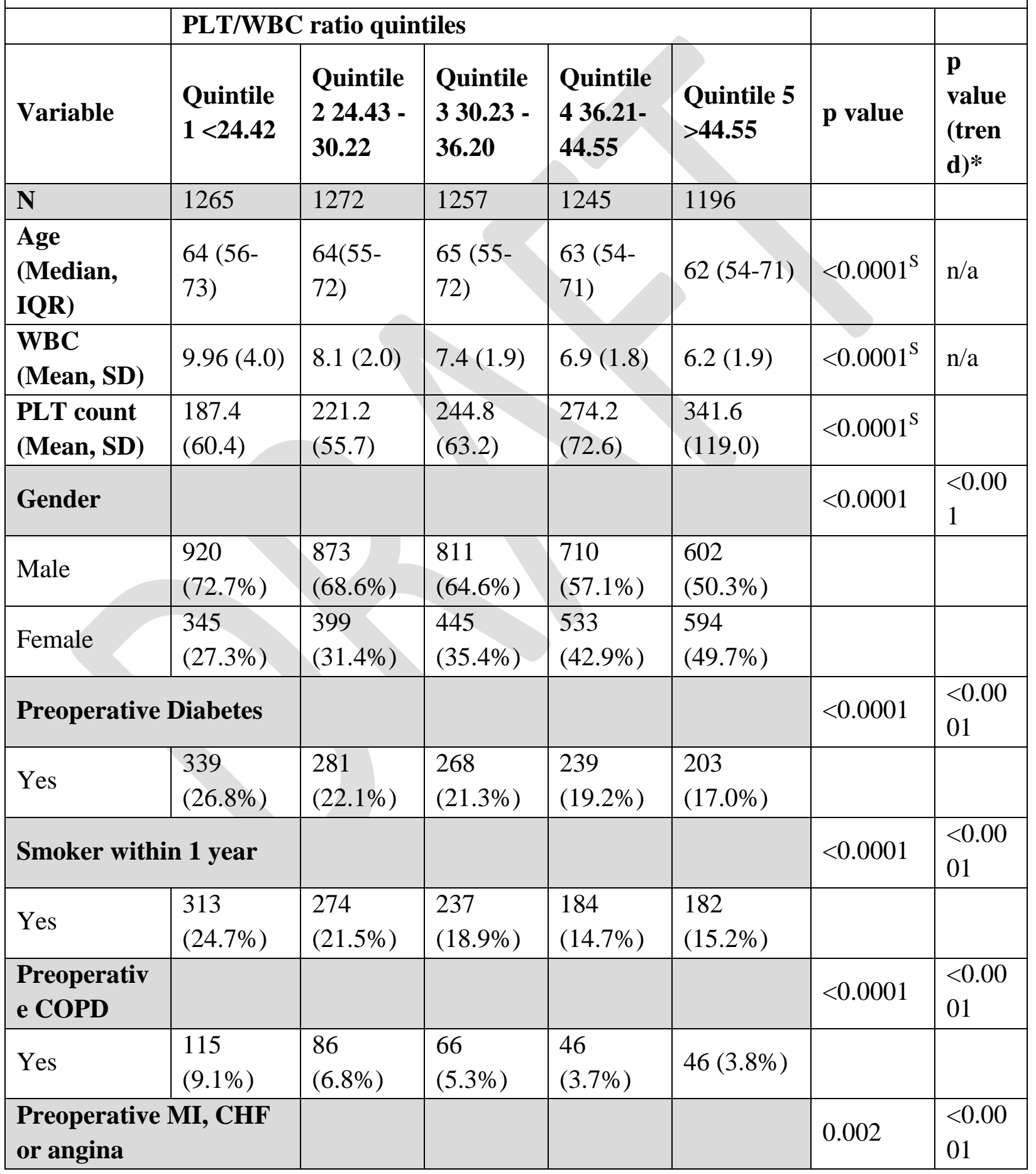


WBC-PLT ratio predicts complications after $R N$

\begin{tabular}{|c|c|c|c|c|c|c|c|}
\hline Yes & 68 (5.4\%) & $\begin{array}{l}63 \\
(5.0 \%)\end{array}$ & $\begin{array}{l}54 \\
(4.3 \%)\end{array}$ & $\begin{array}{l}43 \\
(3.5 \%)\end{array}$ & 30 (2.5\%) & & \\
\hline $\begin{array}{l}\text { ASA } \\
\text { Classificatio } \\
\text { n }\end{array}$ & & & & & & $<0.0001$ & $\mathrm{n} / \mathrm{a}$ \\
\hline 1 & 12 (1.1\%) & $\begin{array}{l}10 \\
(0.8 \%)\end{array}$ & $\begin{array}{l}24 \\
(1.9 \%)\end{array}$ & $\begin{array}{l}24 \\
(1.9 \%)\end{array}$ & $26(2.2 \%)$ & & \\
\hline 2 & $\begin{array}{l}307 \\
(24.3 \%)\end{array}$ & $\begin{array}{l}409 \\
(32.2 \%)\end{array}$ & $\begin{array}{l}445 \\
(35.4 \%)\end{array}$ & $\begin{array}{l}460 \\
(36.9 \%)\end{array}$ & $\begin{array}{l}455 \\
(38.0 \%)\end{array}$ & & \\
\hline 3 & $\begin{array}{l}787 \\
(62.2 \%)\end{array}$ & $\begin{array}{l}737 \\
(57.9 \%)\end{array}$ & $\begin{array}{l}695 \\
(55.3 \%)\end{array}$ & $\begin{array}{l}692 \\
(55.6 \%)\end{array}$ & $\begin{array}{l}653 \\
(54.6 \%)\end{array}$ & & \\
\hline 4 & $\begin{array}{l}157 \\
(12.4 \%)\end{array}$ & $\begin{array}{l}116 \\
(9.1 \%)\end{array}$ & $\begin{array}{l}93 \\
(7.4 \%)\end{array}$ & $\begin{array}{l}69 \\
(5.5 \%)\end{array}$ & $62(5.2 \%)$ & & \\
\hline \multicolumn{3}{|c|}{$\begin{array}{l}\text { Preoperative Stroke or } \\
\text { Neurological History }\end{array}$} & & & & 0.271 & 0.473 \\
\hline Yes & 24 (1.9\%) & $\begin{array}{l}23 \\
(1.6 \%)\end{array}$ & $\begin{array}{l}27 \\
(2.1 \%)\end{array}$ & $\begin{array}{l}29 \\
(2.3 \%)\end{array}$ & $14(1.2 \%)$ & & \\
\hline $\begin{array}{l}\text { Preoperativ } \\
\text { e BMI }\end{array}$ & & & & & & $<0.0001$ & $\mathrm{n} / \mathrm{a}$ \\
\hline$<18.5$ & $14(1.1 \%)$ & $\begin{array}{l}7 \\
(0.6 \%)\end{array}$ & $9(0.7 \%)$ & $\begin{array}{l}13 \\
(1.0 \%)\end{array}$ & 25 (2.1\%) & & \\
\hline $18.5-24.9$ & $\begin{array}{l}181 \\
(14.3 \%)\end{array}$ & $\begin{array}{l}191 \\
(15.0 \%)\end{array}$ & $\begin{array}{l}213 \\
(16.9 \%)\end{array}$ & $\begin{array}{l}262 \\
(21.0 \%)\end{array}$ & $\begin{array}{l}326 \\
(27.3 \%)\end{array}$ & & \\
\hline $25-29.9$ & $\begin{array}{l}399 \\
(31.5 \%)\end{array}$ & $\begin{array}{l}419 \\
(32.9 \%)\end{array}$ & $\begin{array}{l}452 \\
(36.0 \%)\end{array}$ & $\begin{array}{l}429 \\
(34.5 \%)\end{array}$ & $\begin{array}{l}416 \\
(34.8 \%)\end{array}$ & & \\
\hline $30+$ & $\begin{array}{l}671 \\
(53.0 \%)\end{array}$ & $\begin{array}{l}655 \\
(51.5 \%)\end{array}$ & $\begin{array}{l}583 \\
(46.4 \%) \\
\end{array}$ & $\begin{array}{l}541 \\
(43.5 \%)\end{array}$ & $\begin{array}{l}429 \\
(35.9 \%)\end{array}$ & & \\
\hline $\begin{array}{l}\text { Functional } \\
\text { Status }\end{array}$ & & & & & & 0.073 & $\mathrm{n} / \mathrm{a}$ \\
\hline Independent & $\begin{array}{l}1217 \\
(96.2 \%)\end{array}$ & $\begin{array}{l}1245 \\
(97.9 \%)\end{array}$ & $\begin{array}{l}1220 \\
(97.1 \%)\end{array}$ & $\begin{array}{l}1218 \\
(97.8 \%)\end{array}$ & $\begin{array}{l}1170 \\
(97.8 \%)\end{array}$ & & \\
\hline $\begin{array}{l}\text { Partially } \\
\text { dependent }\end{array}$ & $40(3.2 \%)$ & $\begin{array}{l}21 \\
(1.7 \%)\end{array}$ & $\begin{array}{l}29 \\
(2.3 \%)\end{array}$ & $\begin{array}{l}21 \\
(1.7 \%)\end{array}$ & 19 (1.6\%) & & \\
\hline $\begin{array}{l}\text { Totally } \\
\text { Dependent }\end{array}$ & $2(0.2 \%)$ & 0 & 0 & $3(0.2 \%)$ & $3(0.3 \%)$ & & \\
\hline Not reported & $6(0.5 \%)$ & $\begin{array}{l}6 \\
(0.5 \%)\end{array}$ & $8(0.6 \%)$ & $3(0.2 \%)$ & $4(0.3 \%)$ & & \\
\hline Race & & & & & & $<0.0001$ & $\mathrm{n} / \mathrm{a}$ \\
\hline African & 76 (6.0\%) & $\begin{array}{l}98 \\
(7.7 \%)\end{array}$ & $\begin{array}{l}98 \\
(7.8 \%)\end{array}$ & $\begin{array}{l}122 \\
(9.8 \%)\end{array}$ & $\begin{array}{l}149 \\
(12.5 \%)\end{array}$ & & \\
\hline Caucasian & 1046 & 1017 & 1032 & 972 & 859 & & \\
\hline
\end{tabular}


WBC-PLT ratio predicts complications after RN

\begin{tabular}{|c|c|c|c|c|c|c|c|}
\hline & $(82.7 \%)$ & $(80.0 \%)$ & (82.1\%) & (78.1\%) & (71.8\%) & & \\
\hline Other & $\begin{array}{l}143 \\
(11.3 \%)\end{array}$ & \begin{tabular}{|l|}
157 \\
$(12.3 \%)$ \\
\end{tabular} & $\begin{array}{l}127 \\
(10.1 \%)\end{array}$ & $\begin{array}{l}151 \\
(12.1 \%)\end{array}$ & $\begin{array}{l}188 \\
(15.7 \%)\end{array}$ & & \\
\hline $\begin{array}{l}\text { Dialysis } \\
\text { dependent }\end{array}$ & & & & & & $<0.0001$ & $\begin{array}{l}<0.00 \\
01\end{array}$ \\
\hline Yes & 78 (6.2\%) & $\begin{array}{l}61 \\
(4.8 \%)\end{array}$ & $\begin{array}{l}55 \\
(4.4 \%)\end{array}$ & $\begin{array}{l}45 \\
(3.6 \%)\end{array}$ & 36 (3.0\%) & & \\
\hline $\begin{array}{l}\text { Chronic } \\
\text { Steroid use }\end{array}$ & & & & & & $<0.0001$ & $\begin{array}{l}<0.00 \\
01\end{array}$ \\
\hline Yes & $81(6.4 \%)$ & \begin{tabular}{|l|}
53 \\
$(4.2 \%)$ \\
\end{tabular} & $\begin{array}{l}43 \\
(3.4 \%)\end{array}$ & $\begin{array}{l}41 \\
(3.3 \%)\end{array}$ & 38 (3.2\%) & & \\
\hline Anemia & & & & & & $<0.0001$ & $\begin{array}{l}<0.00 \\
1\end{array}$ \\
\hline Yes & $\begin{array}{l}486 \\
(38.4 \%) \\
\end{array}$ & \begin{tabular}{|l|}
430 \\
$(33.8 \%)$ \\
\end{tabular} & $\begin{array}{l}486 \\
(38.7 \%)\end{array}$ & $\begin{array}{l}596 \\
(47.9 \%) \\
\end{array}$ & $\begin{array}{l}736 \\
(61.6 \%) \\
\end{array}$ & & \\
\hline
\end{tabular}

s statistical test performed using analysis of variance (ANOVA) with Dunnett's C post-hoc testing; *Cochrane Armitage test for trend

\begin{tabular}{|c|c|c|c|c|c|c|c|}
\hline & PLT/WBC & ratio quin & les & & 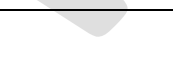 & & \\
\hline & Quintile 1 & $\begin{array}{l}\text { Quintile } \\
2\end{array}$ & Quintile 3 & $\begin{array}{l}\text { Quintile } \\
4\end{array}$ & $\begin{array}{l}\text { Quintile } \\
5\end{array}$ & $\begin{array}{l}\text { Pearson } \\
\text { chi- } \\
\text { square p } \\
\text { value }\end{array}$ & $\begin{array}{l}\text { Cochrane } \\
\text { Armitage } \\
\text { test for } \\
\text { trend }\end{array}$ \\
\hline \multicolumn{6}{|c|}{ Infectious complications } & $<0.0001$ & $<0.0001$ \\
\hline No & $\begin{array}{l}1155 \\
(91.3 \%)\end{array}$ & $\begin{array}{l}1186 \\
(93.2 \%)\end{array}$ & $\begin{array}{l}1196 \\
(95.1 \%)\end{array}$ & $\begin{array}{l}1195 \\
(96.0 \%)\end{array}$ & $\begin{array}{l}1138 \\
(95.2 \%)\end{array}$ & & \\
\hline Yes & $\begin{array}{l}110 \\
(8.7 \%)\end{array}$ & $\begin{array}{l}86 \\
(6.8 \%)\end{array}$ & $61(4.9 \%)$ & $\begin{array}{l}50 \\
(4.0 \%)\end{array}$ & $\begin{array}{l}58 \\
(4.8 \%)\end{array}$ & & \\
\hline \multicolumn{6}{|c|}{ Sepsis } & $<0.0001$ & $<0.0001$ \\
\hline No & $\begin{array}{l}1210 \\
(95.7 \%)\end{array}$ & $\begin{array}{l}1248 \\
(98.1 \%)\end{array}$ & $\begin{array}{l}1238 \\
(98.5 \%)\end{array}$ & $\begin{array}{l}1225 \\
(98.4 \%)\end{array}$ & $\begin{array}{l}1180 \\
(98.7 \%)\end{array}$ & & \\
\hline Yes & $55(4.3 \%)$ & $\begin{array}{l}24 \\
(1.9 \%)\end{array}$ & $19(1.5 \%)$ & $\begin{array}{l}20 \\
(1.6 \%)\end{array}$ & $\begin{array}{l}16 \\
(1.3 \%)\end{array}$ & & \\
\hline \multicolumn{6}{|c|}{ Surgical Site Infections } & 0.383 & $\begin{array}{l}\text { Not } \\
\text { performed }\end{array}$ \\
\hline No & $\begin{array}{l}1237 \\
(97.6 \%)\end{array}$ & $\begin{array}{l}1241 \\
\text { (98.2\%) }\end{array}$ & $\begin{array}{l}1234 \\
(98.4 \%)\end{array}$ & $\begin{array}{l}1225 \\
(98.4 \%)\end{array}$ & $\begin{array}{l}1178 \\
(98.5 \%)\end{array}$ & & \\
\hline
\end{tabular}



WBC-PLT ratio predicts complications after RN

\begin{tabular}{|c|c|c|c|c|c|c|c|}
\hline Yes & $28(2.2 \%)$ & $\begin{array}{l}31 \\
(2.4 \%)\end{array}$ & $23(1.8 \%)$ & $\begin{array}{l}20 \\
(1.6 \%)\end{array}$ & $\begin{array}{l}18 \\
(1.5 \%)\end{array}$ & & \\
\hline \multicolumn{8}{|c|}{ Pneumonia } \\
\hline No & $\begin{array}{l}1239 \\
(97.9 \%)\end{array}$ & $\begin{array}{l}1247 \\
(98.0 \%)\end{array}$ & $\begin{array}{l}1240 \\
(98.6 \%)\end{array}$ & $\begin{array}{l}1236 \\
(99.3 \%)\end{array}$ & $\begin{array}{l}1182 \\
(98.8 \%)\end{array}$ & 0.028 & 0.005 \\
\hline Yes & $26(2.1 \%)$ & $\begin{array}{l}25 \\
(2.0 \%) \\
\end{array}$ & $17(1.4 \%)$ & $9(0.7 \%)$ & $\begin{array}{l}14 \\
(1.2 \%) \\
\end{array}$ & & \\
\hline \multicolumn{8}{|c|}{ Urinary Tract Infection } \\
\hline No & $\begin{array}{l}1239 \\
(97.9 \%)\end{array}$ & $\begin{array}{l}1251 \\
(98.3 \%)\end{array}$ & $\begin{array}{l}1243 \\
\text { (98.9\%) }\end{array}$ & $\begin{array}{l}1236 \\
(99.3 \%)\end{array}$ & $\begin{array}{l}1175 \\
(98.2 \%)\end{array}$ & 0.042 & 0.144 \\
\hline Yes & $26(2.1 \%)$ & $\begin{array}{l}21 \\
(1.7 \%)\end{array}$ & $14(1.1 \%)$ & $9(0.7 \%)$ & $\begin{array}{l}21 \\
(1.8 \%)\end{array}$ & & \\
\hline \multicolumn{6}{|c|}{ Major complications } & 0.655 & $\begin{array}{l}\text { Not } \\
\text { performed }\end{array}$ \\
\hline No & $\begin{array}{l}1215 \\
(96.0 \%)\end{array}$ & $\begin{array}{l}1231 \\
(96.8 \%)\end{array}$ & $\begin{array}{l}1219 \\
(97.0 \%)\end{array}$ & $\begin{array}{l}1206 \\
(96.9 \%)\end{array}$ & $\begin{array}{l}1160 \\
(97.0 \%)\end{array}$ & & \\
\hline Yes & $50(4.0 \%)$ & $\begin{array}{l}41 \\
(3.2 \%)\end{array}$ & $38(3.0 \%)$ & $\begin{array}{l}39 \\
(3.1 \%)\end{array}$ & $\begin{array}{l}36 \\
(3.0 \%)\end{array}$ & & 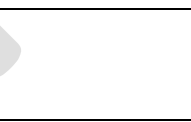 \\
\hline \multicolumn{6}{|c|}{ Bleeding requiring transfusion } & $<0.0001$ & 0.0009 \\
\hline No & $\begin{array}{l}1078 \\
(85.2 \%) \\
\end{array}$ & $\begin{array}{l}1133 \\
(89.1 \%) \\
\end{array}$ & $\begin{array}{l}1109 \\
(88.2 \%)\end{array}$ & $\begin{array}{l}1095 \\
(88.0 \%) \\
\end{array}$ & $\begin{array}{l}962 \\
(80.4 \%) \\
\end{array}$ & & \\
\hline Yes & $\begin{array}{l}187 \\
(14.8 \%)\end{array}$ & $\begin{array}{l}139 \\
(10.9 \%)\end{array}$ & $\begin{array}{l}148 \\
(11.8 \%)\end{array}$ & $\begin{array}{l}150 \\
(12.0 \%) \\
\end{array}$ & $\begin{array}{l}34 \\
(19.6 \%) \\
\end{array}$ & & \\
\hline
\end{tabular}




\begin{tabular}{|c|c|c|c|c|}
\hline Variable & $\begin{array}{l}\text { Odds } \\
\text { Ratio* }\end{array}$ & $\begin{array}{l}\text { Lower 95\% } \\
\text { CI }\end{array}$ & Upper $95 \%$ CI & p-value \\
\hline \multicolumn{5}{|c|}{ Infectious Complications } \\
\hline Quintile 1 & 1.88 & 1.33 & 2.66 & $<0.0001$ \\
\hline Quintile 2 & 1.58 & 1.10 & 2.25 & 0.013 \\
\hline Quintile 3 & 1.11 & 0.76 & 1.62 & 0.60 \\
\hline Quintile 4 & 0.87 & 0.59 & 1.29 & 0.48 \\
\hline Quintile 5 & \multicolumn{4}{|c|}{ REFERENCE } \\
\hline \multicolumn{5}{|c|}{ Major Complications } \\
\hline Quintile 1 & 1.04 & 0.66 & 1.65 & 0.87 \\
\hline Quintile 2 & 0.94 & 0.58 & 1.50 & 0.78 \\
\hline Quintile 3 & 0.89 & 0.55 & 1.43 & 0.63 \\
\hline Quintile 4 & 0.98 & 0.61 & 1.56 & 0.91 \\
\hline Quintile 5 & \multicolumn{4}{|c|}{ REFERENCE } \\
\hline \multicolumn{5}{|c|}{ Bleeding Requiring Transfusion } \\
\hline Quintile 1 & 0.83 & 0.66 & 1.05 & 0.114 \\
\hline Quintile 2 & 0.65 & 0.51 & 0.83 & 0.001 \\
\hline Quintile 3 & 0.67 & 0.53 & 0.85 & 0.001 \\
\hline Quintile 4 & 0.62 & 0.49 & 0.79 & $<0.0001$ \\
\hline Quintile 5 & \multicolumn{4}{|c|}{ REFERENCE } \\
\hline
\end{tabular}

*Adjusted for the effect of age, diabetes history, smoking history, COPD history, cardiac history, ASA classification, neurological history, body mass index (BMI), gender, mobility, race, undergoing dialysis, chronic steroid use and anemia history. 